\title{
A NEW PRETEXT TO ATTACK CHURCH - ALLEGED DISCRIMINATION OF WOMEN
}

\author{
PhD. Cristian GAGU \\ Associate Professor, University Dunărea de Jos- Galati \\ ROMANIA \\ Email: pr.cristi_gagu@yahoo.com
}

\begin{abstract}
The present study aims to answer in terms of teaching the Christian Orthodox faith of the often accusations of discrimination made by the Orthodox Church representatives of various media associations promoting feminist movement. In formulating the response were considered linguistic arguments, namely the original meaning of the term "discrimination" in Latin and its semantic evolution in different foreign languages, scriptural arguments, due to was shown who is the authority of the legislature in the Church and which is its legitimacy, which is the basis of the laws issued by it and their purpose in life of the Church and arguments of the folk tradition.
\end{abstract}

Keywords: discrimination; feminist movement; priesthood/ordination; religious tradition; apocryphal gospels;

\section{INTRODUCTION}

Under the pretext of the fight for human rights, nonconformists, misfits and rebels today, few in number, that's right, compared with those among whom they live, express noisy discontent with the rules of the members of which are claiming that their rights are violated, because they are restricted the freedom of speech and expression and they are therefore discriminated against others, say that part of the public and the media are very sensitive. Lately, under the influence of the more aggressive feminist movement, but also of some hidden interests of those who are "enemies of the cross of Christ" (Flp.3,18), such accusations have been made and the Orthodox Church in an attempt to discredit the doctrine of faith, traditions and customs which they defend it. This is the reason I considered trying to explain the natural subject of whether or not the teachings of any church or discriminatory practices in any aspect whatsoever.

To illustrate this issue it is necessary to know the exact meaning of the concepts to which we refer, as often happens, although using the same vocabulary, not to speak the same "language", giving the same word different meanings, which is why we fail to make ourselves understood, communication being thus faulty.

Etymologically, the word discriminate, discrimination comes from Latin. The verb discrimino, -arre means to distinguish, to separate, and the feminine noun discriminatio, onis is translated separately and the masculine discriminator, -oris designates the one who makes the difference ${ }^{1}$.

In terms of the two meanings, to distinguish and to separate each human person, due to its rational and free will endowed by God, having a choice between at least two options,

\footnotetext{
${ }^{1}$ Latin-Romanian Dictionary, ed.G.Guţu, Scientific and Encyclopedic Publishing House, Bucharest, 1983, p. 355
} 
commits a series of normal discriminatory acts, and to distinguish between good and evil, virtue and sin, between the good and the wicked, between the righteous and the unrighteous or to separate the peaceful from the most violent, the most healthy one from that who has a contagious disease, and examples such can continue.

In terms of everyday speech, the terms we refer to have acquired another meaning than the one made in Latin. Thus, the English verb discrimination, besides the meaning to recognize a distinction between persons or things, means treating a person or group worse / better than others and the noun discrimination designates inter alia the different treatment usually bad, of a person or group over others ${ }^{2}$.

In Romanian the verb to discriminate has the meaning to separate, distinguish, discriminate and the noun discrimination is defined as the difference, but as a policy by which a state or a group of citizens of a state are deprived of certain rights based on unfounded grounds ${ }^{3}$.

From the explanations provided by O.D.C.E. and D.E.X. actual language you notice a new meaning, the definition of the two terms, referring to a person, a group or class of persons subjected to bad treatment ${ }^{4}$ compared to others. A more complete explanation of DEX discusses three very important elements in the correct understanding of the negative sense of the term discrimination, namely politics, rights and unfounded reasons. Having regard to all these considerations it results that in a negative sense discrimination is the worse and worse treatment that confronts a person, a group or class of persons in comparison with other community members, violation or arbitrary refusal, for unfounded reasons, of recognized rights of others, due to the orientation or attitude of an institution, a part or the community as a whole, racial, national, ethnic, social, cultural, religious, age, sex, etc.

Therefore, when someone accuses that he/she has been discriminated by violation or denying the exercise of certain rights, there should be considered whether the rights relied on them and were recognized by the legislature, the authority legally empowered to recognize or grant rights at the expense of community members or a person. Consideration should be also given to the legitimacy of legal and / or moral legislative authority to give someone, person, group, class or community as a whole, duties, competence, the basis on which the rights and purpose are recognised.

These elements, the existence or not of the rights, the authority that may accept or not those rights, the legitimacy and its jurisdiction, the basis on which or not the rights and the purpose are recognized, all these must be taken into account when making the Church accused of discrimination.

\section{THE LEGISLATIVE AUTHORITY IN THE CHURCH AND ITS LEGITIMACY}

From the outset it should be pointed and emphasized, the fundamental fact that, unlike the institutions that are founded and operate through human laws, being therefore likely to be unfair and discriminatory towards certain groups or categories of persons, the Church is a divine-human institution, being founded by Jesus Christ through His sacrifice on the Cross, He Himself being the head of the Church - "Christ is head of the Church"

\footnotetext{
${ }^{2}$ Oxford Advanced Learner's Dictionary of Current English (O. D. C. E.), fifth edition, New International Students'Edition, Oxford University Press, 1995, p.330-331

${ }^{3}$ The explanatory dictionary of the Romanian language (D.E.X.), 2nd edition, Publisher Universe Enciclopedic, Bucharest, 1998, p.307

${ }^{4}$ From O.D.C.E. results that discrimination can have a positive character, by treating "better" preferentially some than others
} 
$\left(\right.$ Ef.5,23) ${ }^{5}$. Therefore, the supreme legislative authority in the Church is God the incarnate Son, Jesus Christ and His authority and legitimacy can be challenged only by the lawless, the enemies of the Cross, and then the discussion is pointless. The Head of the Church is without sin - "Who of you proves Me of sin?" (In.8,46) - then "righteous statutes of the Lord" (Ps.18,8) and "trustworthy are all His commandments, reinforced forever, made in truth and justice"(Ps.110,7-8). It's obviously the law of the New Testament expressed in the Gospel in the nine beatitudes, the commandments and the evangelical counsels by which the Saviour "fulfilled" the law of the Old Testament - "I have not come to destroy, but to fulfil" (Mt. 5.17). Sending the Apostles to preach the Gospel, together with the grace of the Holy Spirit (Mt.28,18-20), the Saviour invested with the authority and legitimacy to lead the Church and therefore to adopt and establish, according to the evangelical law, rules by which to govern the Church and through it to meet both the domestic needs and the challenges coming from outside. By sharing the grace of the Holy Spirit to the bishops and priests in the sacrament of ordination, the Holy Apostles sent, in their turn, the authority and legitimacy to these - "take heed to yourselves and all the flock of which the Holy Ghost hath made you overseers, to shepherd the Church of God"(FA20, 28) - and, through them, the Church gathered in ecumenical councils or local.

Outside councils, by virtue of its faithful universal priesthood (1 Ptr.2, 9; 1 In.2, 20,27), the Church expresses its authority, as pleromas of his spiritual children, and the customs and traditions related to religious life or arising therefrom, to the extent that they are, in turn, in conformity with the Gospel and Church teaching law.

\section{BASIS OF LAW AND ITS PURPOSE}

The basis on which Jesus Christ founded the Church through the sacrifice of the Cross and gave people the law of the New Testament is the love for "God is love" (1 Jn. 4,16). God in His love includes all people without discrimination -"He makes His sun rise on the evil and on the good and makes it rain on the just and on the unjust"'(Mt.5,45) - and us commanded to love our fellow beings without discrimination all (Lc.10,29-37), including the enemy - "love your enemies..."(Mt.5,44).

On the basis of God's love commandment - "Thou shalt love the Lord thy God ... is the great and first commandment it"(Mt.22,37) embodied in the love of neighbour - "Love your neighbour as yourself"'(Mt.22 39) and "who loves God should love his neighbour"(1 Jn. 4,20-21) - expressed the Church throughout the ages, and has the authority to adopt rules by which to establish and to guide the conduct of all aspects of church life. And as the law of love is not discriminatory (Mt. 5,45), or other rules of church life are not or might not be so to anyone, since all those spring from love. As to the purpose for which Jesus Christ instituted the new law of the Gospel and which the Church aims for each of his spiritual children, it is their sanctification in this life $(\mathrm{In} .17,17 ; 19)$ and the acquisition of eternal life (Mt.18,11). From the brief exposure of the above it is clear that the Church cannot be accused of discrimination, because where Christ is "there is neither Greek nor Jew, circumcised nor uncircumcised, barbarian, Scythian, slave nor free, but Christ is all and in all" (Col. 3,11). If there are still some who bring it such accusations, they are guilty of ignorance of church life and rules on which it is based or, what is more serious, bad faith and malice.

\footnotetext{
${ }^{5}$ See also Mt.28, 18, 1 Co.15, 27, Ef.1, 22; 4, 15, Col.1, 18; 2, 10. Biblical texts are quoted from the Holy Bible, the Holy Synod jubilee edition (Bartolomeu Anania), Bucharest, 2001

${ }^{6}$ See also 2 Co.5, 21
} 


\section{THE FEMINISM OR THE STRUGGLE FOR EQUAL RIGHTS OF MEN AND WOMEN, THE MAIN SOURCE OF GENERATING ACCUSATIONS AGAINST THE CHURCH DISCRIMINATION}

Specifically speaking, the accusations of discrimination to the Orthodox Church come overwhelmingly from the feminist movement or supporters and sympathizers of this movement and refers to the situation of women in the Church in relation to men, incriminating, specifically, non-acceptance to the priestly ministry, the primacy of men over women in the Church, as well as some teachings or traditions that seem to discriminate against women. Those who provide such excuses to the Orthodox Church should be aware that in reality only Church really does not discriminate against women to men. Unlike any other human institution that can recognize the equal rights of the sexes, but cannot guarantee, for various reasons, equal opportunities in exercising those rights and the achievement of the aim pursued by them, the Church guaranteeing equal opportunities of women and men in achieving the ultimate goal which, as we have shown, it is salvation. Jesus Christ shares the grace of the Holy Spirit as gift in the Church through the sacraments and other sanctifying works in women and men equally and without discrimination. And there is no discrimination as regards the obligations men and women have in the Church. Proof of this situation are the Church sinaxars where can be found the saints and venerated as such, equally martyr men and martyr women, saints and pious.

As regards the accession of women to the stage of priestly ministry in the Church, this issue was not raised in the first nineteen centuries of existence of the Church, although in the first centuries, on the one hand, coming overwhelmingly from among the pagans, some Christians might raise the issue, citing the model of pagan cults where there were priestesses and, on the other hand, in the church there was a bunch of deaconesses ${ }^{7}$ who were ordained $^{8}$ and vowed chastity, but whose ministry was strictly social in nature. Being so, from the beginning, understood and widely accepted by all Christians that the priestly ministry is reserved exclusively for party men, the Church has not discussed this issue in any council, so it was not specifically regulated in any namely canon. Under this situation of the Church there is both the Old Testament Law, which God ordained priesthood is reserved for men's Party (Is. XXVIII-XXIX), and especially the Church's tradition, based on the example of Jesus Christ who chose as His apostles, of those who have followed the course of his work of preaching the Gospel twelve men, among them being women too. After the ascension of Christ the Saviour, when it came to replacing Judas Iscariot in the apostolic ministry, it was considered choosing a man, not of any woman, even though they were present, along with the holy Apostles and other disciples, Mary and myrrh-bearing women. Sitting in the midst of all this, the number of which was "like a hundred and twenty", St. Peter addressed only "men brethren", saying that "must have in these men, who gathered with us during the time Jesus was with us ... one of them to be a witness with us of His resurrection"(F.A.1,21-22).

The descent of the Holy Spirit on Pentecost as tongues of fire that only face the Apostles (F.A. 2), who were thus clothed with power from up high and so consecrated as priests of the new law of Jesus Christ, confirms that the sacramental ministry, priesthood has been entrusted only to the male. Following the example of their Lord, the Holy Apostles chose and ordained as bishops and priests of the communities they have established, only men (F.A. 20,17; 28; 1Tim.3,2,12; 5,17).

\footnotetext{
${ }^{7}$ Rom. 16, 1; can. 19, sin. I ec.; can. 15 , sin. the 4th ecumenical synod.

${ }^{8}$ Chyrotesia is an ierourgia, while ordination is the Sacrament
} 
Aware that in the New Testament there is no argument, no text that can be cited in the accession of women to priestly ministry to give legitimacy to their struggle to achieve this goal, proponents of this case are trying to "rewrite" the Saviour's life and history of Early Church on the basis of so-called "new evidence" feeling, the mystery of the Church, which they produce in the apocryphal gospels and other writings apocryphal ${ }^{9}$ nature. Based on these writings one is trying to posit the idea that among the apostles of Saviour there was a woman, Mary Magdalene, who had a special relationship with the Saviour and by virtue of that relationship would have enjoyed a privileged position before Him in relation to the other apostles. To argue its advocates call this idea including arguments that, given the time and used sources has not the slightest relevance to the matter in which all these are invoked. It is, on the one hand, the famous painting of The Last Supper by Leonardo Da Vinci in which, according to them, on the right of Saviour there was not the Apostle and Evangelist John but Mary Magdalene, concluding from this that, since she attended the dinner, Mary Magdalene was part of the Holy Apostles, having the same status as them, enjoying her gift and sacramental priesthood. On the other hand, in support of this theory there are put forward various contemporary writings, each more fanciful, lacking any scientific substrate, but claims to science, and who claim that revealing information known only original members of secret organizations whose roots go back in history to the time of Jesus.

Looked closely, both sources and quotes from the texts they are proving to be lacking in credibility and relevance. Gospel of Philip and the Gospel of Mary ${ }^{10}$, to which reference Apocrypha those campaigning for women's ordination in the Church by virtue of sacramental priests alleged that as partaker and Mary Magdalene are unreliable because they are of Gnostic origin. In addition, even in these writings show that Mary Magdalene would be counted among the Apostles, one conclusion in this regard is forced. Apocryphal texts not only say that Mary Magdalene Saviour "loved her more than all the disciples" 11 or "than all the women" ", and that the Holy Apostles Peter and Andrew doubted that the Saviour would have discovered her secret teachings, which he had shared with others ${ }^{13}$. Moreover, even in the Apocrypha blamed on her when she encourages the Apostles to go with courage to preach the Gospel, Mary Magdalene does not include herself among the Apostles, but says "His grace will be with you forever and will protect you" 14 .

As for the interpretation of the painting of Da Vinci, it cannot be taken into account simply because it is in flagrant contradiction with what was documented in writing even the one who stood head on the breast of the Saviour to dinner, Apostle and Evangelist Joan (In.13,23; 21.20).

Beyond these arguments irrelevant and inconsistent theologically much more serious is, in terms of the fight to eliminate the alleged discrimination of women in the Church in relation to man and accepted the priestly ministry, the emergence in theology, a new directions, feminist theology, for which the traditional arguments in support of the Church in the Sacrament accepting the ordination of women have no value.

\footnotetext{
${ }^{9}$ Non-authentic writings or whose authenticity is questionable, falsely attributed to authors whose authority is recognized that the Church does not recognize them and they are among the canonical religious books

${ }^{10}$ Published in The Gnostic Gospels, translation, introductory study and notes by Anton TOTH, Herald Publishing House, Bucharest, 2005

${ }^{11}$ Gospel of Philip, vol.cit., p.167 și Gospel of Mary, vol.cit., p.296

${ }^{12}$ Gospel of Mary, vol.cit., p.291

${ }^{13}$ Gospel of Mary, vol.cit., p.298

${ }^{14}$ Gospel of Mary, vol.cit., p.291
} 
For example, an article of Sister Nonna Verna Harrison, who has sought to present the objections and counter-arguments put forward by the feminist theology against the practice of accepting women in priestly liturgical service that divine authority, which underlies the argument of tradition, the strongest otherwise justifying the practice of the Church in this respect, to which I referred above and that will not be enough. "Proponents say that ordaining women is a serious injustice ... that they be excluded just because of their sex, from a form of service which can achieve. If only motivation as divine authority, it would make God not only arbitrary and unfair. (...) So if God commanded indeed, He must have another reason, of such importance to justify that exclusion otherwise unfair. It cannot be based solely on divine authority itself " 15 .

Searching for "a motivation deeper spiritually and theologically"16 beyond the argument of divine authority means, on the one hand, to question the wisdom of God and His righteousness, in flagrant contradiction with the revelation of Holy Scripture, according to which "Truth is the beginning of thy words, and all the judgments of thy righteousness shall endure forever"'(Ps.118, 160) and "Oh, the depth of the riches and wisdom and knowledge of God! How are His ways of unexplored and His judgments unfathomable"(Rm.11, 33), and on the other hand, we lose time in vain in theological disputes, "For who has known the mind of the Lord? Or who has been his counsellor?"(Rm.11,34) "As my counsels are not as your counsels, nor your ways my ways as well, says the Lord. Because how far is heaven from earth, in so far is My way from your ways and your thoughts from My mind"'(Is.55: 89). If divine authority is not sufficient, then any other argument is superfluous.

And yet, without seeking to answer these objections and rebuttal of feminist theology step by step, we will try very briefly to show that this theological approach starts from a false premise.

From the perspective of the human "nature" argument, the feminists strongly accuse that women are barred from ordination "just because of their sex"17. He started from the premise that sexuality is the criteria that guides the Church in the mystery man's acceptance and rejection of women's ordination to the holy sacrament, is a grave error. Equally counterproductive and wrong seems to me, by the way, and trying to discover the author's article cited "meaning the priest masculinity" 18 and argues it from the patristic theological perspective. As some arguments rose by some Orthodox theologians to justify the rejection of women from the priesthood, as the moral and spiritual inferiority of woman, her flowers or her universal subordination to $\operatorname{man}^{19}$, they are completely unfounded and are offensive to women.

I think the priest masculinity and therefore sexuality are not the answer to this problem. Man and woman cannot be reduced to their sexuality or any common human nature, facts which we cannot ignore any longer, because the two are more than that. Through the act of creation God hypostasized human nature for the first time in the person of a man, Adam, and only after then of a woman, Eve, whom he had named "Woman, because she was taken from her husband"(Fc. 2.23). Although they share a common human nature, Adam and Eve, and therefore men and women are different not only sexually but psychosomatically too, without being inferior, and therefore subordinate to one another in

\footnotetext{
15 Nonna Verna HARRISON, Orthodox arguments against ordaining women, translated by Iuliu Blaga Adrian in Theological Studies, Series III, third year, No.2, 2007, p.123

${ }^{16}$ N.V. HARRISON, Orthodox arguments..., p.123

${ }^{17}$ N.V. HARRISON, Orthodox arguments ..., p.123

${ }^{18}$ N.V. HARRISON, Orthodox arguments ..., p.124-125, 137-140

${ }^{19}$ N.V. HARRISON, Orthodox arguments ..., p.125,127
} 
any respect whatsoever. Beyond the universality of human nature that unites all people ontologically, but also the uniqueness of every human being partly, man and woman are different due to different specific gifts that God has endowed them in creation.

The response should be sought, perhaps in domestic life and relations between persons of the Holy Trinity, Church paradigm for life. Because "God is Spirit”(Jn. 4,24), "the eternal existence of divine hypostases such limitations and divisions based on sex" which are totally inappropriate and leads to heresy, are absent ${ }^{21}$, as very correctly states the author quoted article. And yet, God is revealed as God the Father, God the Son and God the Holy Spirit and the name by which we call the three Persons of the Trinity are very important in order to understand the internal relationships between them. St. Gregory Palamas wrote that the name of "Father" that we call the One without Beginning implies logically to "give birth" and the "Son" given to the Born, "that the Son is the Son of the Father and brings to mind the Father" as the name "Father immediately brings to mind the name of the Son"22. The two names, Father and Son, which involves "giving birth", although seem to appoint two persons of the male gender, transcend the idea of sexuality and define the relationship of fatherhood - lineage exists in the Trinity between One without Beginning and One Born.

This lineage paternity - relationship between Father and Son in eternity plan is fully the paradigm for another birth for eternity, "not from blood, nor from bodily will, nor from the will of man, but from God"(Jn. 1:13), "from up", "from water and Spirit"(Jn. 3, 3.6) is, to those who believe and confess that Jesus Christ is the Son of God incarnate, and that celebrates the sacramental priesthood. The receiving ordination as priest becomes the spiritual father of all his spiritual children, whom born and reborn with his grace through the Holy Spirit to eternal life and the other sacraments of the Church's sanctifying work.

The spiritual birth through the sacramental priesthood being entrusted exclusively to man means that God, who is neither arbitrary nor unfair in judgment and in His judgments, has entrusted women another but only of them, the motherhood, birth of sons flesh. She does really fulfil herself only in motherhood, and when she conceives a new human creation she is working together with the Holy Spirit, springing life into her womb.

Unfortunately, just under the influence of the feminist movement, claiming women's right to accede to stage of the sacramental priesthood in the Church, women are more prone to not make working the sacred gift that she was endowed by God and which defines par excellence that of childbirth -"and Adam called his name of his wife Eve, because she is the mother of all living" (Gen. 3,20).

The sacramental priesthood being, therefore, entrusted to men and this consisting not only in function of sanctifying, but in the teaching and the ruling image of the priesthood of Jesus Christ, the woman is not allowed either to teach or to lead others in the Church. St. Paul is very emphatic in this regard, teaching that "in all churches of the saints, women should remain silent during the church meetings; Because they are not permitted to speak"(1 Co.14,34) and "not to teach another"(1 Tim.2,12), but "the woman should listen quietly with all subjection" (1 Tim.2,11). This teaching of the Apostle Paul, justified both by the Old Testament Law, and the fact that "Adam was first created, then Eve; and Adam was

\footnotetext{
${ }^{20}$ N.V. HARRISON, Orthodox arguments ..., p.128

${ }^{21}$ N.V. HARRISON, Argumente ortodoxe..., p.129

${ }^{22}$ St Gregory PALAMAS, Words evidence. First word that the Holy Spirit does not proceed from the Son too, but only from the Father, in Complete works, vol.I, translation, notes, introductory study by Cristian Chivu, Patristic Publishing House, București, 2005, p.155
} 
not deceived; but the woman being deceived didn't listen to the commandment"'(1 Tim.2,13$14)$, is counted among the other "commandments of the Lord", whose purpose is keeping the laws of churches and in the Church, "for God is not the author of confusion, but of peace"(1 Co.14,33). Instead, as noted by Nonna Harrison, "there is no reason why women cannot exercise other ministries such as the work of charitable or missionary, teaching and counselling, and care for the sick, the poor and elderly"23, on which the Church calls for them, and which they all fulfil with faith and love.

From the above it cannot be concluded that the Church would somehow discriminate the woman in relation to man. On the contrary. By His incarnation from the Virgin Mary, Jesus Christ restored the dignity of woman before the fall and from the outset members of the early Christian communities were aware of this new state of affairs. St. Paul reminds the women in his letters as very important helpers in preaching the Gospel, and in the Epistle to the Ephesians is quite clearly stated that the ratio of men and women in the family and in the church, should be modelled as the relationship between Christ and the Church (Ef.5 22-33). If the men's side is given precedence at different liturgical moments in the Church, this tradition subsumes the teaching of the Apostle Paul who stated about keeping ordinance in the Church, and this preference is one of honour. It stems from the love and respect shown by the woman for the man in the family, the model Church-Christ being extended to the Church, and not otherwise.

In the Orthodox Church, the faithful guardian of the teachings of Jesus Christ and his holy Apostles, there is, apart from the sacramental priesthood, a number of traditions related to different holidays or times of serious liturgical moments that can be attended only by men, and not by women. Some of these traditions, especially the most popular among the Christians, who are accompanying or following some liturgical celebrations and moments involving many believers, were the occasion to bring accusations that the Church discriminates against women. It is the case of tradition of fishing the Holy Cross when a bishop or priest throws it into the water on the feast of Theophany, after the consecration of high water, to which only men can participate ${ }^{24}$. Although this rule has not been reinforced by the Church in any written canon, it is part of the tradition of church life, gaining the character of an unwritten law, which means that it is in general use of the whole Orthodox Church, that it was tacitly accepted by Church, that it was also accepted voluntarily by the spiritual children of the Church and it has been in practice for a period of great time ${ }^{25}$.

About how important it is tradition for people, especially when linked to a religious event, folklore testifies Romanian people. There are many popular religious customs and traditions, some of pagan origin inherited and perpetuated until today, where, after the case, women are not accepted, such as Călușarii, or the men as in the case of dancing girls from Căpâlna, to name but two examples. There are also a number of traditions and customs of different important liturgical life of the Christian, of bathing the baby by godmother after he was baptized, dressing and arranging the bride before the wedding and undressing her after the wedding at which only women may participate, according to the tradition men being forbidden without them somehow feeling discriminated against, and the examples could continue. And no doubt, such examples do exist in the traditions and customs of all nations,

\footnotetext{
${ }^{23}$ N.V. HARRISON, Orthodox arguments..., p.124

${ }^{24}$ One such case happened at the Feast of Theophany in Braila in 2007

${ }^{25}$ Moral Orthodox Theology, mitropolit dr. Nicolae MLADIN, diac. prof. dr. Orest BUCEVSCHI, prof. dr. Constantin PAVEL, diac. prof. dr. Ioan ZĂGREAN, vol.1, Alba Iulia, Reunification Publishing House, 2003, p.198-199
} 
Christian or not, being accepted, respected and passed on, to the new generations by those they encounter, these representing an overwhelming majority in their communities.

\section{RIGHTS DISCRIMINATED BY THE WOMAN WHO FIGHTS HER ALLEGED DISCRIMINATION BY THE CHURCH}

Struggling to remove some alleged discriminations and to acquire rights which God and the Church have never put about her, the modern feminist woman, repeats somehow, at another level, the fault of the first woman, therefore that of being deceived that it would be "equal to God"(Fc.3,5) and that she can be equal to man that can be in his place, the place of the forbidden fruit being taken by prohibited gift of priesthood. While squandering her energies to prove that she can be like the man, the woman spoils the gift of childbirth, or simply refuses the result of this gift, thus discriminating the sacred right and duty to serve God in maternity, but divine gift entrusted exclusively to her. Motherhood with all that this implies, all feelings and emotional states manifested in the love of the baby and care for his life, to whose defence the true mother sacrifices her own life, reason to assert that "motherhood is a particular form of female kenosis"26. This is what differs fundamentally from psychosomatic level the man from woman. Only motherhood, through which the woman herself is fulfilled and is saved - "but she shall be saved through child birth, if she simply stays in faith, love and holiness"(I Tim.2,15) - proves that opinion according to which "a global designation of tasks as masculine and others as feminine has (...) strong social implications and (...) devastating" that "would affect all women and men"27 is wrong at least in part, the ministries that result from maternity being more appropriate to woman's sensibility. Some of these rights / duties arising from maternity are beautifully captured by the author of the poem "Women's rights":

"The right to serve and to love,

The right, to be merciful,

The right, to gently care for little children,

To grow them up, teach, reprimand, and counsel,

The right when everyone sleeps to watch them all,

The right the dark in light to turn,

With gentle dignity to crown,

The another's burden and hardships to bear,

The right when hard times overflow,

The strong faith to support

The right to be a full woman,

True, pious and pure kindness:

That's the best right of a woman." 28

These lyrics are, I believe, the best and most beautiful response that can and should give the Church to the modern feminist Christian woman, these reminding her rights and gifts that have been given and the services that she has been called by God and the Church, particularly important for the service of the Church and society, which honour and ennobles her.

\footnotetext{
${ }^{26}$ Paul EVDOKIMOV, The mystery of love. The holiness of married life in the light of Orthodox tradition, translated by Gabriela Moldoveanu, verifying and improving the translation by pr.lect. univ. dr. Vasile Răducă, București, 1994, p.158

${ }^{27}$ N.V. HARRISON, Orthodox arguments..., p.127

${ }^{28}$ Pr. Gheorghe PERVA, The Woman in light of Christianity, Arad, 1940, p.126
} 


\section{BIBLIOGRAPHY:}

[1] The Holy Bible [Sfânta Scriptură], the Holy Synod jubilee edition (Bartolomeu Anania), Bucharest, 2001

[2] Latin - Romanian Dictionary [Dicționar Latin - Român], ed.G.Guţu, Scientific and Encyclopedic Publishing House, Bucharest, 1983

[3] Oxford Advanced Learner's Dictionary of Current English, fifth edition, New International Students'Edition, Oxford University Press, 1995

[4] The explanatory dictionary of the Romanian language [Dicționarul Explicativ al Limbii Române], 2nd edition, Publisher Universe Enciclopedic, Bucharest, 1998

[5] The Gnostic Gospels [Evanghelii gnostice], translation, introductory study and notes by Anton TOTH, Herald Publishing House, Bucharest, 2005

[6] Nonna Verna HARRISON, Orthodox arguments against ordaining women [Argumente ortodoxe împotriva hirotonirii femeilor], translated by Iuliu Blaga Adrian in Theological Studies [Studii Teologice] Series III, third year, No.2, 2007,

[7] Sf.Grigorie PALAMA, Words evidence. First word that the Holy Spirit does not proceed from the Son too, but only from the Father [Cuvintele doveditoare. Cuvântul întâi că Duhul Sfânt nu purcede și de la Fiul, ci numai de la Tatăl], in Complete works [Opera completă], vol.I, translation, notes, introductory study by pr.Cristian Chivu, Patristic Publishing House, București, 2005

[8] Pr.Gheorghe PERVA, The Woman in light of Christianity [Femeia în lumina creștinismului], Arad, 1940 